\title{
Who is Who? Identifying the Different Sub-groups of Secondary Stakeholders within a Community: A Case Study of the Niger Delta Region of Nigeria Communities
}

\author{
Oluyomi A. Osobajo ${ }^{1}$, David Moore ${ }^{2}$ \\ ${ }^{1}$ The Scott Sutherland School of Architecture and Built Environment, Robert Gordon University, Scotland, \\ United Kingdom \\ ${ }^{2}$ The Scott Sutherland School of Architecture and Built Environment, Robert Gordon University, Scotland, \\ United Kingdom \\ Correspondence: Oluyomi A. Osobajo, The Scott Sutherland School of Architecture and Built Environment, \\ Robert Gordon University, The Sir Ian Wood Building, Riverside East, Garthdee Road, Aberdeen, AB10 7GJ, \\ United Kingdom.
}

Received: May 16, 2017

doi:10.5539/ibr.v10n9p188
Accepted: August 14, 2017

Online Published: August 21, 2017

URL: https://doi.org/10.5539/ibr.v10n9p188

\begin{abstract}
The Nigerian oil and gas industry (NOGI) has over time been dominated by the Nigerian government and oil producing companies (OPCs). The influences of the community stakeholder on OPCs in the last three decades have been expressed in diverse ways by different community sub-groups through their concerns and interests, some of which have severely impacted on the NOGI. Community within this context is categorised as a primary stakeholder, while the sub-groups are secondary stakeholders that emerge from within the community. Hence, the success of the NOGI largely depends on the Nigerian government and the oil producing companies, and other players such as Non-Governmental Organisations recognising the community as a key player and having appropriate knowledge of the different sub-groups of secondary stakeholders within the community in order to understand their intentions, behaviour, interests, influences and interrelations. Such knowledge is relevant to the NOGI's formulation of future oil and gas strategy.
\end{abstract}

This study commences with an overview of the primary stakeholders (i.e. the Nigerian government, OPC and the community), their respective activities, participation and the link between these stakeholders with a specific focus on the NOGI context. Subsequently, various sub-groups of secondary stakeholders within the community and their respective interest(s) are identified in detail.

Keywords: stakeholder, community, oil and gas industry, Niger Delta region, Nigeria

\section{Introduction}

Since the commercial exploration of oil and gas began in Nigeria in 1957 it has grown to become the mainstay of the Nigerian economy (Gray and Karl, 2003). The Nigerian oil and gas industry (NOGI) is the most developed sector within the Nigerian economy; contributing an estimated $80 \%$ of government revenue, about $95 \%$ of total foreign exchange earnings, more than $40 \%$ of the nation's GDP, employing about $10 \%$ of the working population, and being the principal source of foreign direct investment (FDI). The majority of the operations and activities within the NOGI take place within the Niger Delta Region of Nigeria (NDRN). The region has experienced underdevelopment, local unrest and conflicts due to misalignment of priorities among the following main stakeholders; oil producing companies (both local and International), communities within the NDRN, and the government (i.e. various government agencies, the local government, state government and federal government) (Akpomuvie, 2011; Obi, 2010; Omofonmwan and Odia, 2009; Emoyan, 2008; Opukri and Ibaba, 2008; Omeje, 2006; Eweje, 2006; Frynas, 2005; Frynas, 2000). The impact and influence of the various communities within the NDRN on the NOGI has increasingly become of concern over the last three decades (Frynas, 2009; Eweje, 2007; Omeje, 2006). This concern suggests the identification among researchers and practitioners of the community as an emerging key stakeholder (Idemudia, 2007; Eweje, 2007; Idemudia and Ite, 2006). The impact of the community as a stakeholder on the NOGI cannot be over emphasised due to the latter's unique activities and operations within the NDRN. 
The concept of stakeholder has received commendable attention from researchers and scholars within the management field of study (Clarkson 1995). Freeman's (1984) seminal work on the stakeholder concept has contributed to the widespread use of the theme in management literature (Reed et al., 2009; Atkin and Skitmore, 2008; Laplume et al., 2008; Welch and Jackson, 2007; Buchholz et al., 2005; Margolis and Walsh 2003; Gibson, 2000; Rowley, 1997; Donaldson and Preston 1995). This reflects the acceptance and acknowledgement among researchers and scholars of the significant position of stakeholders as "any group or individual who can affect or is affected by the achievement of the organisation's objectives" (Freeman 1984, pg. 64). Understanding the community group as a key stakeholder within the NOGI is paramount to the success of the industry. This is because the community has a significant effect on the operations and activities of the OPCs. Likewise, researchers and scholars alike have argued that acknowledging and accommodating stakeholder interest in managerial decisions is a prerequisite to achieving success (Cleland, 1986; Freeman and Evan, 1990; Donaldson and Preston, 1995; Diallo and Thuillier, 2005; Olander and Landin, 2005). This suggests that the operations and acti vities of the OPCs should take into consideration various stakeholders' such as the community needs. Hence, the need to explore and understand the combination of the interest of the various community sub-groups in the NDRN.

This research study therefore aim is to identify and understand the various sub-groups of secondary stakeholders and their respective interest(s) within the community in the NOGI context.

\section{Literature Review}

\subsection{An Overview of the Nigeria Oil and Gas Industry (NOGI)}

Oil was first discovered in Nigeria in 1956, in the region of a community called Oloibiri, in Bayelsa State within the NDRN whilst oil exportation commenced in 1958. The industry currently produced an average of 2.5 million bbl per day. Nigeria National Petroleum Company (NNPC) statistics evidence the country has a proven crude oil reserve of 28.2 billion barrels, the majority of which are located in the NDRN. Nine out of the thirty-six independent states comprising Nigeria are located within the NDRN. Nigeria became a member of the Organisation of Petroleum Exporting Countries (OPEC) in July 1971. The main purpose being to safeguard her interests in the international oil market while OPEC exists to regulate member countries' annual production in order to influence oil prices in the international market (Ogwo, 2016; Edomah et al., 2016; Colgan, 2014; Takon et al., 2014; Khan, 1994).

Prior to 2015, crude oil exploration and production activities occurred mainly in nine states (i.e. Abia, Akwa Ibom, Bayelsa, Cross River, Delta, Edo, Imo, Ondo and Rivers) as shown in figure 1a. Howe ver, Lagos and Anambra have recently joined the league of oil producing states (Oil and Gas, 2016; Okpamen, 2015) as shown in figure $1 \mathrm{~b}$. Figure 2 shows the three major sectors with their respective associated activities within the NOGI. However, not all of these activities occur within the NDRN. The operations and activities of the OPC within this industry are comprised of these three sectors. In addition, the performance of these activities are within the capacity and power of the OPC and Nigeria's government respectively, therefore making the OPC and the Nigerian government the two key stakeholders within the NOGI (Idemudia, 2009). However, Osobajo and Moore (2017), and Orubu et al (2004) asserted that it is imperative to recognise community involvement within the NOGI. This is because all onshore operations and activities are performed within the communities situated in the Niger Delta region (Omofonmwan and Odia, 2009; Eweje, 2006; Frynas, 2001; Ikelegbe, 2001). Nannen (2004) concluded that the non-inclusion of the community as a key stakeholder is a major cause of the growing level of restiveness in the NDRN since 1956.

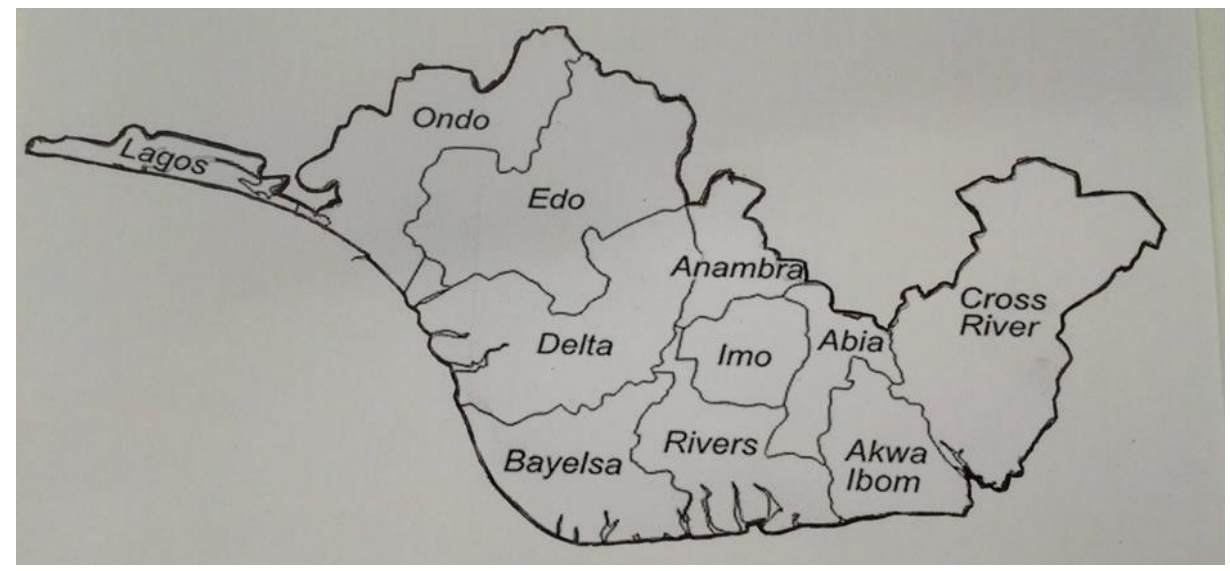

Figure 1a. Map of the Niger Delta Region (Author generated) 


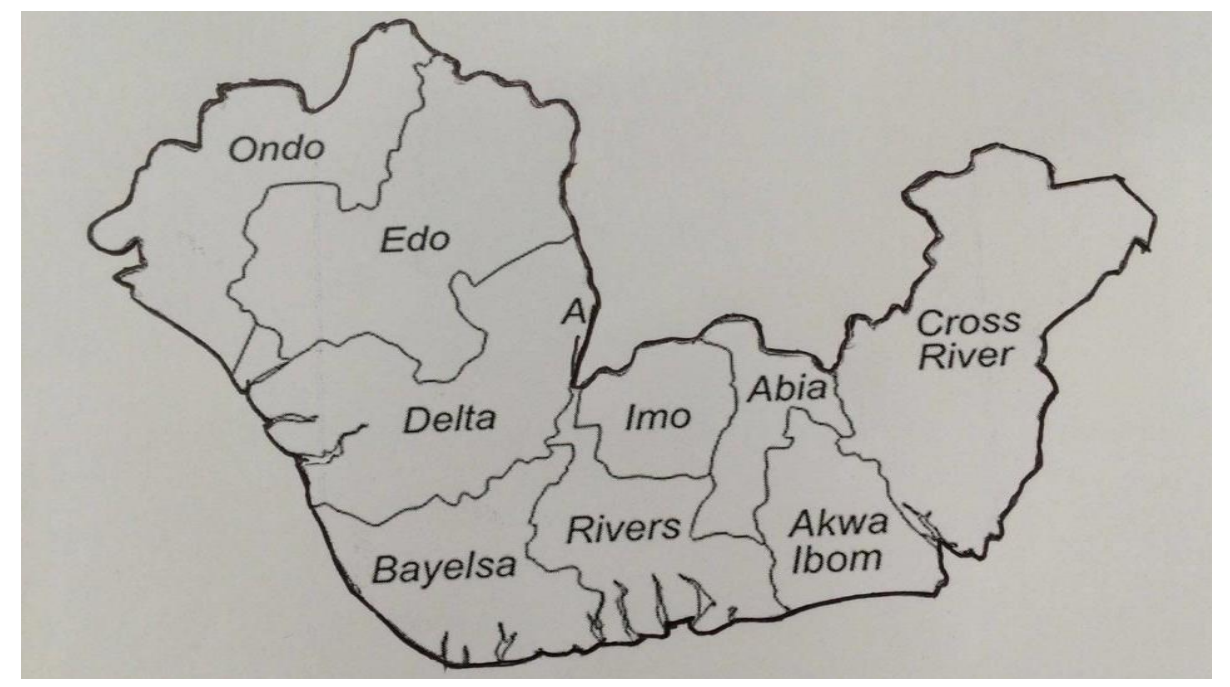

Figure 1b. Map of Oil Producing States in Nigeria (Author generated)

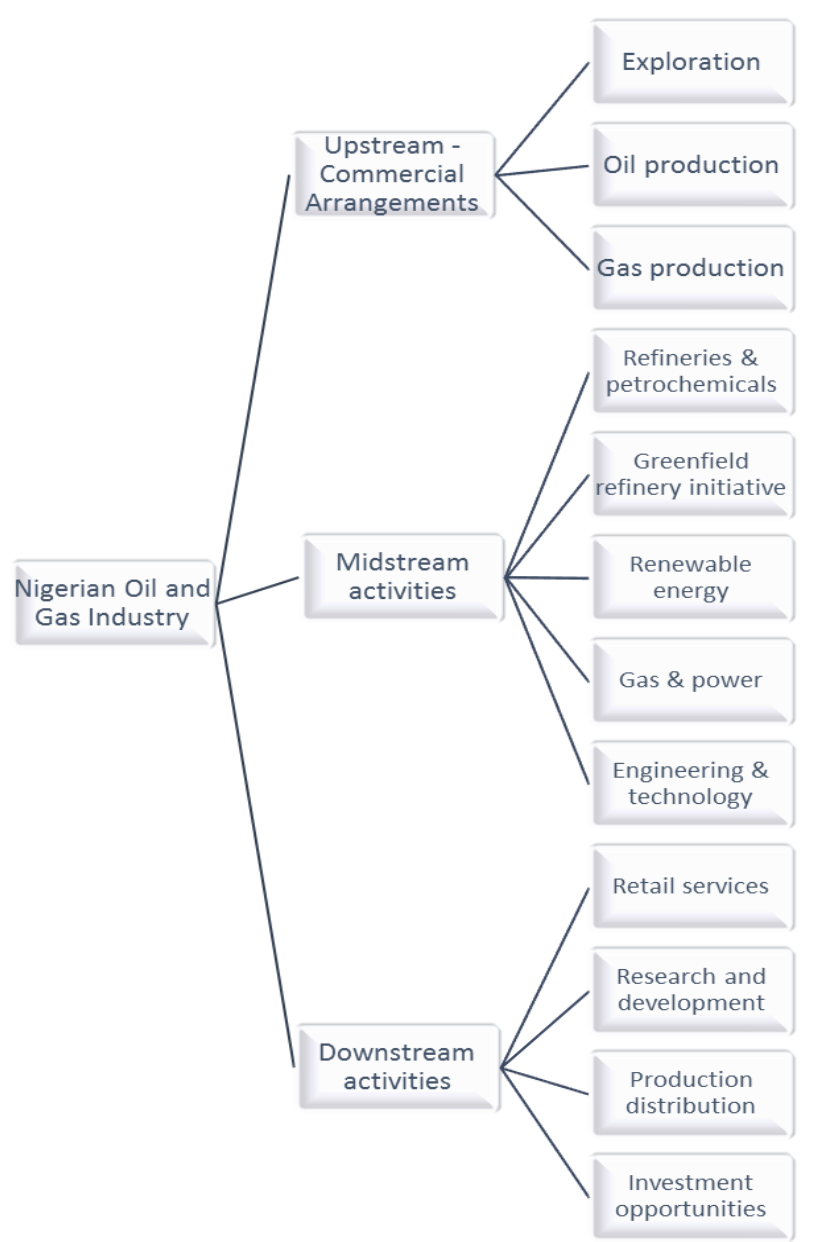

Figure 2. Sectors and Activities within the NOGI (Author generated)

\subsubsection{Upstream Sector}

The Nigerian upstream sector comprises: licence acquisition by oil producing companies from the Nigerian government, pre-drilling exploration, exploration and de velopment drilling, production, and abandonment and restoration (NNPC, 2014). This sector searches for and recovers crude oil and natural gas underwater and/or underground and brings it to the surface for production. Arguably, it could be viewed that the Nigerian 
government and the OPC are the key or main stakeholders operating in this sector. However, community involvement cannot be denied because it would be a major challenge for OPC to carry out its operations without the cooperation from the community of operation (Oluduro and Oluduro, 2012). This is consistent with Musa et al (2013: 112) assertion that "the upstream sector of the oil and gas industry of Nigeria presently lies wholly in the Niger Delta region". At present (i.e. 2016), the recent discoveries in Lagos and Anambra states are not sufficiently developed to change this assertion.

\subsubsection{Midstream Sector}

This sector focuses on how refined petroleum products and/or crude oil is transported or transferred (by rail, trucks, pipeline or oil tankers), stored and marketed. This sector ensures safe and appropriate movement of crude oil from the point of production to refineries and subsequently to the marketers. As in the upstream sector, community consent is also required in order to allow the laying, and ensuring safety, of the oil pipelines passing through the community. Hence, the Nigerian government, OPC, and the community should be collectively viewed as the key or main players in this sector.

\subsubsection{Downstream Sector}

The downstream sector focuses on the refining of extracted crude oil and/or natural gas. Products like liquefied petroleum gas, diesel oil, fertilizers, petroleum coke, jet fuel, gasoline, antifreeze, pesticides, rubbers, plastics and synthetic rubber, to mention a few, are derived during the refining process of crude oil and/or natural gas. Nigeria has four refineries; three of which are located in NDRN (i.e. Rivers - 2, and Delta -1) and the fourth refinery is located in Kaduna, which is situated in the Northern part of the country. Arguably, the community experiencing contamination of industrial effluents with oil-related residues is inevitable (Sojinu et al., 2010). Hence, the community could also be termed as a key or major player in this sector along with the Nigerian government and the OPC.

\subsection{An Overview of Niger Delta Region of Nigeria (NDRN)}

The NDRN is referred to as the largest wetland in the world (Eweje, 2007). It covers $112,111 \mathrm{~km}$ and is located in the south on the coastal region of Nigeria (NDDC, 2004). There are 606 oil fields in the region out of which 355 are on-shore while the remaining 251 are offshore (NNPC, 2016). The region has an estimated population of 35 million inhabitants with roughly $75 \%$ of the people living in rural areas (NDDC, 2010). The region's critical importance to the Nigerian economy is not reflected in the prosperity of the population; there is a high level of poverty evidenced in the region. Wurthmann (2006) asserted that over $\$ 600$ billion worth of oil revenue has been generated from the region since the 1960s, yet the NDRN suffers from "administrative neglect, crumbling social infrastructure and services, high unemployment, social deprivation, abject poverty, filth and squalor, and endemic conflict" (UNDP, 2006). This has further degenerated into frequent conflicts and violence between communities within the NDRN and the OPCs operating in the region (Oyefusi, 2013). Eweje (2007) argued that the pressure experienced by OPCs in the region was because of the Nigerian government's inefficiency in performing its responsibilities towards the development of the region. Idemudia (2010) concluded that under-development contributed to the emergence of violence and conflicts in the region. All these factors have put the OPC under pressure to meet the needs of the community.

\subsection{Who Is a Stakeholder?}

The stakeholder concept has several definitions (Mitchell et al 1997). Therefore, giving a generally acceptable description or definition of who is a stakeholder has remained a major issue for scholars (Phillips and Reichart, 2000). Various scholars (Starik, 1995; Freeman and Reed, 1983) have referred to a stakeholder as an interest group, claimant, influencer and constituent. Freeman (1984: 46) referred to a stakeholder as "any group, organisation or individual who can affect or is affected by the achievement of the organisation's objectives". This definition suggests an interdependent relationship between the organisation and its stakeholders (Hillman and Keim, 2001) and that the achievement of these objectives are subject to cooperation and support from the stakeholders (Minoja, 2012). However, there is disagreement as to whether stakeholders should either (or both) be considered as an entity affected by an organisation's objective(s), or restricted to those that are crucial for the achievement of organisation an objective(s) (Friedman and Miles, 2006). In addition, Schiller et al. (2013) argued that this definition widens further an organisation's stakeholder composition to include other entities that may be affected by the organisation's actions, while Cummings and Patel (2009) listed the employees, customers, shareholders, community and suppliers as the most essential stakeholders who can influence the achievement of an organisation's objectives.

Donaldson and Preston (1995) define a stakeholder as any individual or group whose interest has at least some 
fundamental value based on its legitimate interest in the organisation. Likewise, Henriques and Sadorsky (1999), Berman et al (1999) and Agle et al (1999) argued that taking into account the interest of different stakeholders is important. They however concluded that organisations tend to consider only those stakeholders whose interest(s) the organisation think are important. In the same manner, Diallo and Thuillier (2005) and Olander and Landin (2005) argued in favour of the inclusion of stakeholders' demands and interests in managerial decision making as being a prerequisite to achieving success. Of significant concern in respect to this standpoint is determining what constitutes a legitimate interest of a stakeholder. Table 1 reveals suggested definitions of who a stakeholder is.

Table 1. Summary of Definition of a Stakeholder (summarised from the literature)

\begin{tabular}{|c|c|}
\hline DEFINITIONS & REFERENCES \\
\hline $\begin{array}{l}\text { Those groups without whose support the organisation } \\
\text { would cease to exist. }\end{array}$ & Stanford, 1963; Bowie, 1988. \\
\hline $\begin{array}{l}\text { Are depending on the firm in order to achieve their } \\
\text { personal goals and on whom the firm is depending for its } \\
\text { existence. }\end{array}$ & Rhenman, 1964; Ahlstedt and Jahnukainen, 1971. \\
\hline $\begin{array}{l}\text { Can affect or is affected by the achievement of the } \\
\text { organization's objectives. }\end{array}$ & $\begin{array}{l}\text { Freeman and Reed, 1983; Freeman, 1984; Freeman and Gilbert, } \\
\text { 1987; Freeman, 1988; Brenner, 1995; Freeman, 2002; Andersen, } \\
\text { 2005; Sutterfield et al., 2006; Edum-Fotwe and Price, } 2009 .\end{array}$ \\
\hline $\begin{array}{l}\text { Who have an interest and/or a stake in the outcome of } \\
\text { the project. }\end{array}$ & $\begin{array}{l}\text { Cle land, 1986; Savage et al., 1991; Wright, 1997; McElroy and } \\
\text { Mills, 2000; Boddy and Paton, 2004; Bourne and Walker, 2006; } \\
\text { El-Gohary et al., 2006; Javed et al., 2006; Olander, 2007; Walker } \\
\text { et al., 2008; Couillard et al., 2009. }\end{array}$ \\
\hline Claimants who have a claim on the firm. & $\begin{array}{l}\text { Cornell and Shapiro, 1987; Cleland, 1989; Freeman and Evan, } \\
\text { 1991; Hill and Jones, 1992; Clarkson, 1995; Langtry, } 2009 .\end{array}$ \\
\hline Groups to whom the corporation is responsible. & Alkhafaji, 1989. \\
\hline $\begin{array}{l}\text { Are those that gain or lose because of perceived success } \\
\text { in project implementation. }\end{array}$ & Dinsmore, 1990. \\
\hline In relationship with an organization. & Thompson et al., 1991; Hill and Jones, 1992. \\
\hline Constituents who have a legitimate claim on the firm. & $\begin{array}{l}\text { Hill and Jones, 1992; Brenner and Cochran, 1993; Donaldson } \\
\text { and Preston, } 1995 .\end{array}$ \\
\hline Have one or more of the kinds of stakes in business. & Carroll, 1993; Starik, 1995; Carroll and Buchholtz, 2011. \\
\hline $\begin{array}{l}\text { Interact with and give meaning and definition to the } \\
\text { corporation. }\end{array}$ & Wicks et al., 1994; Nasi, 1995. \\
\hline Are placed at risk because of a firm's activities. & Clarkson, 1994. \\
\hline \multicolumn{2}{|c|}{$\begin{array}{l}\text { Furthermore, Phillips and Reichart (2000) argued that only humans (i.e. people) who are capable of interacting } \\
\text { with one another should be referred to as a potential stakeholder. Mitchell et al (1997) opposed this standpoint } \\
\text { because they asserted that a non-human stakeholder, such as the natural environment, exerts its influence using } \\
\text { other stakeholders. However, Phillips and Reichart (2000) perspective is deemed important in the context of this } \\
\text { study because of their emphasis on interaction among stakeholders, although the natural environment could be } \\
\text { viewed as a potential stakeholder represented by those people within it. Hence, the emergence of stakeholder by } \\
\text { proxy, which Soukhanov (1984: 948) referred to as 'the state, quality or fact of being near or next in space, time } \\
\text { or order" to an organisation. This further suggests that a lack of interaction among stakeholders will result in } \\
\text { misunderstandings and the inability of an organisation to carry out its activities and operations effectively (Nasi, } \\
\text { 1995). It could also be argued that this perspective on the definition of who a stakeholder is emphasises the } \\
\text { importance of the role of humans, and their interactions, in the fulfilment (or otherwise) of an organisation's } \\
\text { objectives. }\end{array}$} \\
\hline
\end{tabular}

Some scholars define a stakeholder as an individual or group whose support is crucial to the existence of an organisation (Bowie, 1988). Freeman and Reed (1983) stated that any organisation that falls within this category should be viewed as dependent on identified individuals or groups for its survival. Contrary to this standpoint, Rhenman (1964) argued that individuals or groups depend on the organisation for their survival. Howe ver, the importance of these views to this study is the consistent emphasis on a dependency "relationship" among stakeholders. This further suggests the requirement for a definition to encompass a need for an organisation and its stakeholders to rely on one another for continual of both survival. In addition, this standpoint raises the issue of reciprocity among stakeholders, which involves stakeholders actively coming together in knowledge sharing and value creation activities (Harrison et al., 2010; Bosse et al., 2009).

Similarly, a stakeholder is viewed as an individual or group who is placed at risk or accepts risk because of its involvement in an organisation's operations or activities (Clarkson, 1994). This suggests that an individual or group should be exposed to some risk before they can be referred to as a stakeholder. This is because a stakeholder must have a stake in an organisation, which is of value; financial or human capital (Clarkson, 1994). 
Freeman (1984) often referred to a stake as "interest" while Carroll and Buchholtz (1996) considered a stake as either a share or an interest in an endeavour. It is worth noting that all these scholars agreed that a stake must involve an element of risk and be of value to its holder. However, Wolfe and Putler (2002) and Rowley (1997) concluded that the definition of a 'stake' remains a point of argument for scholars.

Among the definitions of stakeholders summarised in table 1, it can be concluded that a stakeholder is an individual, group of individuals or an organisation that has either influence, or interest.

\subsubsection{Stakeholder Classification}

Freeman (1984) was among the first scholars to classify stakeholders based on a managerial view. He classified stakeholders as internal and external stakeholders based on a changing business environment. Internal stakeholders are responsible for internal business changes, while external stakeholders are responsible for external business changes. This classification suggests that both the internal and external stakeholders are subjected to boundaries. Furthermore, Savage et al (1991) classified stakeholders based on their ability to cooperate or threaten an organisation within a changing business environment. They classified stakeholders as supportive, non-supportive, marginal, or mixed blessing. Kumar et al (2016: 38) asserted that "supporting stakeholders have a high potential to cooperate and low potential to threaten the organization; marginal stakeholders have low potential to cooperate and threaten; non-supportive stakeholders have a high potential to threaten but a low potential to cooperate; and mixed-blessing stakeholders have a high potential to both cooperate and threaten". In addition, Goodpaster (1991) suggested a stakeholder classification based on ethics and morals. He concluded that stakeholders should be classified as fiduciary and non-fiduciary stakeholders. Fiduciary stakeholders are the stakeholders that the management of an organisation owes an obligation of care and accountability such as keeping a profit maximizing promise, while non-fiduciary stakeholders are people or group of people whose interest(s) must be taken seriously in order to seek creative solutions to disagreement as opposed to exerting influence and/or manipulation. Clarkson (1995) extended Freeman's (1984) assertion of stakeholder classification and concluded that stakeholders should be classified into two categories: primary and secondary. This classification was based on the perceived influence a stakeholder has on an organisation's operations. Likewise, Mitchell et al (1997) stakeholder classification was based on the perceived stakeholder salience, which focuses on the priority given to competing stakeholder claims. Hence, any individual or group "that do not possess any of the above attributes are in fact non-stakeholders, as they do not receive any priority from managers" (Kumar et al., 2016:39).

\subsubsection{Stakeholder Salience and Attributes}

Mitchell et al (1997: 854) defined stakeholder salience as "the degree to which managers give priority to competing stakeholder claims". Likewise, Bundy et al (2013: 353) defined stakeholder salience "as the degree to which a stakeholder's issue resonates with and is prioritized by management", Boesso and Kumar (2016) concluded that stakeholder salience focuses on the extent to which management give priority to the various stakeholder's claim(s). These definitions suggest that stakeholder salience focuses on a manager's ability to interpret how a potential issue will affect an organisation as it attempts to achieve its objectives (Dutton and Jackson, 1987; Bundy et al., 2013). Mitchell et al., (1997: 873) suggested that "Stakeholder salience will be positively related to the cumulative number of stakeholder attributes-power, legitimacy, and urgency - perceived by managers to be present", while Harrison and Freeman (1999) concluded that the number of stakeholder attributes significantly increase stakeholder salience. This suggests that stakeholder attributes help to define the salience of a stakeholder. Hence, an understanding of stakeholder salience has significant effect in using stakeholder attributes such as influence and power, urgency, and legitimacy, which help in the process of identifying key or relevant stakeholders (Mitchell et al., 1997; Magness, 2008). Table 2 reveals the various attributes or elements that scholars have refer to since the pronouncement of stakeholder theory within management discipline (Clarkson 1995; Achterkamp \& Vos, 2008). 
Table 2. Stakeholder attributes (Summarised from the literature)

\begin{tabular}{|c|c|c|}
\hline Author(s) & $\begin{array}{l}\text { Stakeholder } \\
\text { Attributes }\end{array}$ & Attributes Definition \\
\hline $\begin{array}{l}\text { Garcia-Sanchez et al., 2013; Cormier and Magnan, 2003; Choi, } \\
\text { 1999; Mitchell et al., 1997; Roberts, 1992; Freeman, 1984; } \\
\text { Pfeffer, 1981; Dahl, 1957; Weber, } 1947\end{array}$ & $\begin{array}{l}\text { Stakeholder } \\
\text { Power and } \\
\text { influence }\end{array}$ & $\begin{array}{l}\text { The degree to which a stakeholder } \\
\text { can get its will done by others. }\end{array}$ \\
\hline $\begin{array}{l}\text { Mitchell et al., 1997; Grimble and Wellard 1997; Brugha and } \\
\text { Varvasovszky 2000; Chevalier and Buckles 2008; Jepsen and } \\
\text { Eskerod 2009; Neville et al 2011; Ackermann and Eden } 2011\end{array}$ & $\begin{array}{l}\text { Stakeholder } \\
\text { Legitimacy }\end{array}$ & $\begin{array}{l}\text { The degree to which the actions and } \\
\text { inactions of a stakeholder are } \\
\text { accepted by society. }\end{array}$ \\
\hline $\begin{array}{l}\text { Mitchell et al., 1997; Neville et al., 2011; Jonker and Foster, } \\
\text { 2002; Mitchell et al., } 1997\end{array}$ & $\begin{array}{l}\text { Stakeholder } \\
\text { Urgency }\end{array}$ & $\begin{array}{l}\text { The degree to which stakeholder } \\
\text { claims call for urgent action. }\end{array}$ \\
\hline Neville et al., 2011; Driscoll and Starik, 2004; Soukhanov, 1984; & $\begin{array}{l}\text { Stakeholder } \\
\text { Proximity }\end{array}$ & $\begin{array}{l}\text { The degree of closeness between } \\
\text { stakeholders: physical, } \\
\text { psychological and otherwise. }\end{array}$ \\
\hline
\end{tabular}

2.3.3 Potential Key Stakeholders in the NOGI

Scholars (e.g. Chika et al, 2014; Manowong and Ogunlana, 2010) have argued that managing stakeholders effectively begins with the stakeholder identification process. Therefore, stakeholder identification is a fundamental task for an organisation's success (Ballejos and Montagna, 2008; Friedman and Miles, 2006; Freemen, 1984). Hence, stakeholder identification underpins successful stakeholder management (Chapleo and Simms, 2010). Frooman (1999) proposed that stakeholder identification should answer the question of "who are they?". Yang (2014: 839) defines stakeholder identification as the "development of a list of stakeholders", while Wolfe and Putler (2002) view stakeholder identification as the process of identifying relevant stakeholders. Reed et al (2009) concluded that that stakeholder identification is an iterative process. Achterkamp and Vos (2006) asserted that stakeholder identification problems have given rise to the emergence of the development of different theoretical classifications. Figure 3 reveals the potential key stakeholders in the NOGI. The inclusion of these stakeholder groups is because of their evident to interest and the attributes they possess (Stenseke, 2009). However, the community will be assessed in more detail in this paper in order to identify and analyse the various sub-groups of secondary stakeholders.

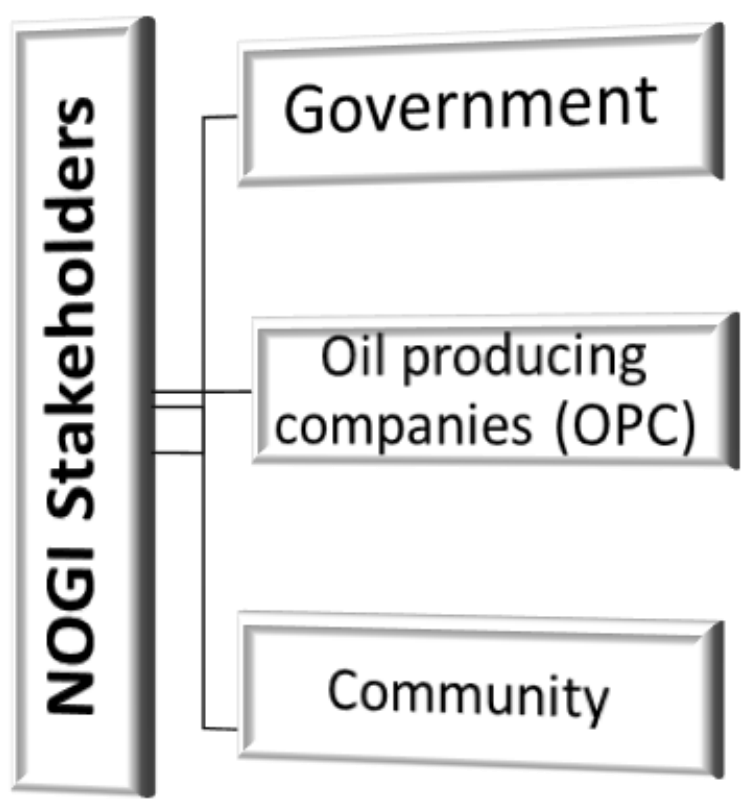

Figure 3. Proposed Key Stakeholders in the NOGI (Author generated)

\subsection{Definition of a Community}

The term community has been defined by different fields of study to connote different meaning. It explains issues of belonging and identity, inclusion and exclusion, difference and similarity, time and place, and processes such 
as modernisation (Delanty, 2003; Silk, 1999; Crow and Allen, 1994; Cater and Jones, 1989; Bell and Newby, 1971). Likewise, Silk (1999: 6) stated that community encapsulates "common needs and goals, a sense of the common good, shared lives, culture and views of the world, and collective action". This standpoint emphasises the communality of the term. In addition, Crow and Allen (1994: 1) focused on the relational aspect of community and concluded that it offers "a convenient shorthand term for the broad realm of local social arrangements beyond the private sphere of home and family but more familiar to us than the impersonal institutions of the wider society". Arguably, it can be perceived that there are various ways in which community as a concept can be approached. Some of which are based upon; the geographical approach (e.g. Mackenzie and Dalby, 2003), the social system approach, which explains social binding between groups or institutions (e.g. Gandy, 2002; Allen and Hamnett, 1995), and the communion approach, which focuses on common practices, beliefs or identity (e.g. Radcliffe, 1999; Lave, 2003). Furthermore, Mulrennan et al (2012) and Koster et al (2012) added that it is important to pay attention to community members who are not involved in a project in order to be aware of their feedback and evaluation. Gusfield (1975), and French and Saward (1975) differentiate between two main approaches to community. First, community is considered as a geographical or territorial location of a community neighbourhood, city or town. Second, community is referred to as a relational paradigm involved with the quality of or character of a human relationship. Kruckeberg and Starck (1988: 23) in support of the former assertion, define community as "the city or area where the organisation is physically located". Durheim (1964) and Anderson (1983) however argued that contemporary society builds community around cohesion, skills and interest as opposed to locality. Wiesenfeld (1996), Robinson (2014), and Farrance et al (2016) in line with their argument termed community as homogenous groups characterised by an emotional bond. This suggests that communities emerge with the passage of time through a dynamic process.

\section{Method and Approach}

This study is part of a larger research programme on how to enhance relationship quality between the OPCs and their HCs within the NDRN. The communities under consideration for this research study are restricted to those within the NDRN. These communities are considered a key stakeholder because of their influence and impact (e.g. economic impacts) within the NDRN. This is in line with Clarkson's (1995) assertion that this type of stakeholder is classified as a primary stakeholder because of its contribution towards the existence of an organisation. This is also consistent with Kumar et al's (2016: 38) assertion that primary stakeholders "are involved in various transactions, and their continuous involvement is necessary for organizations' survival". Considering the research nature and aim, which is to identify and understand the various sub-groups of secondary stakeholders and their respective interest(s) within the community in the NOGI context, face-to-face interviews were used for data collection. This method of data collection involves an interviewer engaging an interviewee (i.e. the research participants) in a discussion on a specific research area in order to gain insight or explore certain issues (Hennink et al, 2010). Although there are nine independent states (i.e. Abia, Akwa Ibom, Bayelsa, Cross River, Delta, Edo, Imo, Ondo and Rivers) within the NDRN, only three of these states (i.e. Bayelsa, Delta and Rivers) were selected for the purpose of data collection. This is because these states are worse affected due to the intensity and nature of oil production and operations, which are mostly onshore (see figure 4). In addition, these states experience the highest level of violence and conflicts compared to the remaining six other states in the NDRN. Table 3 presents the number of interviews conducted in each state. A total of sixteen semi-structured interviews were conducted. The number of interviews conducted in each state and for the whole research was not predetermined, instead it was decided to continue until the researcher reached the point of saturation. This was evidenced during the data gathering process as no new insights were obtained. Bowen (2008, p. 140) defined saturation point to entails "bringing new participants continually into the study until the data set is complete, as indicated by data replication or redundancy". Research participants were selected using selective sampling which is also referred to as purposeful sampling (Coyne, 1997). This is because they have privileged and important information as a result of either or both of their position and/or their direct involvement in the relations and/or negotiation process of their communities with the OPC. Further, the context for the current study also imposed some limitations on the sample selection. The researcher could not gain free access to the various communities within the region due to security reasons (violence and conflicts). Data was analysed using content analysis. Hsieh and Shannon (2005, p. 1278) define content analysis as a "research method for the subjective interpretation of the content of text data through the systematic classification process of coding and identifying themes or patterns". 
Table 3. Details of interviews held (Author generated)

\begin{tabular}{lcc}
\hline & STATES & NUMBER OF FACE-TO-FACE INTERVIEWS CONDUCTED \\
\hline Bayelsa & 5 \\
Delta & 5 \\
Rivers & 6 \\
Total & $\mathbf{1 6}$ \\
\hline
\end{tabular}

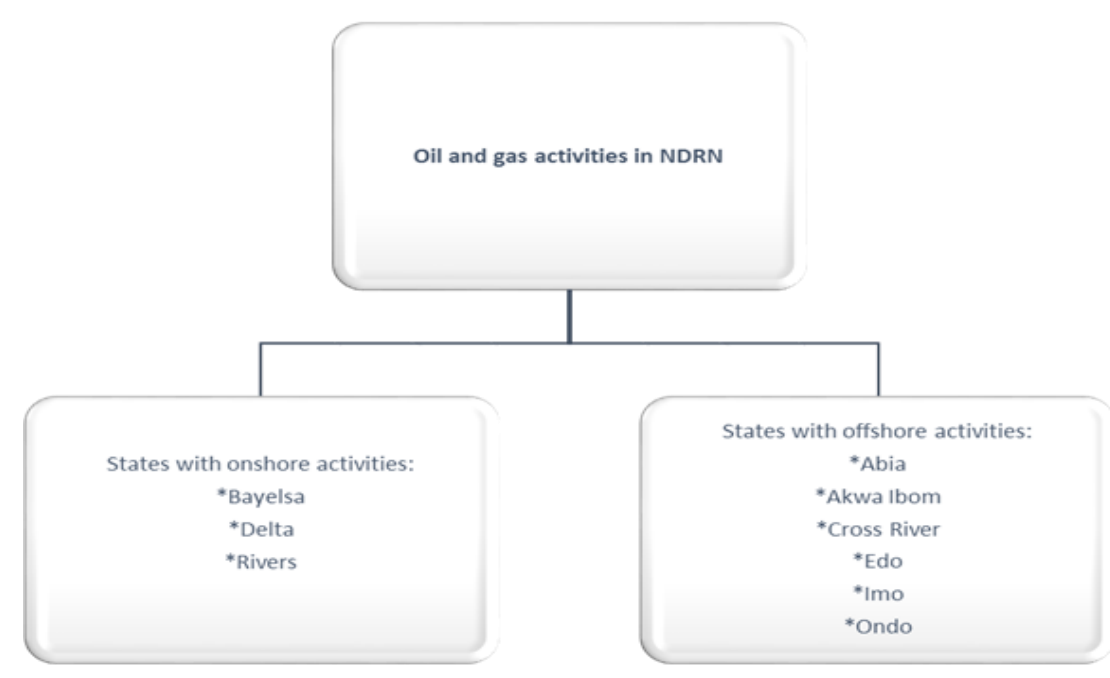

Figure 4. Inshore and offshore activities by State (Author generated)

\section{Results and Discussion}

\subsection{The Niger Delta Community}

Figure 4 reveals four different categories of community stakeholder in the Nigerian oil and gas context as identified by the research participants. These are;

1) The Host communities. Also referred to as the producing communities. The host or producing communities are communities in which OPCs implement onshore activities such as exploration and production.

2) The Transit communities. Communities where OPC pipelines pass through or communities through which crude oil produced is transported.

3) The Terminal communities. Communities where offshore terminal facilities are located due to OPC exploration taking place offshore.

4) The Impacted communities. Communities affected by OPC operations due to their close proximity to OPC facilities.

In line with Mitchell et al's (1997) standpoint on who is a stakeholder, all the aforementioned different categories of community identified by research participants can be regarded as legitimate stakeholders. Furthermore, research participants identified different sub-groups of secondary stakeholders as shown in figure 5. They added that these sub-groups of secondary stakeholders exist in all communities irrespective of the community type. Even though these sub-groups of secondary stakeholders are not directly involved with other key stakeholders within the NOGI, their respective interest(s) affect the community, OPCs, the Nigerian government, and NOGI at large. This is consistent with Kumar et al's (2016: 38) assertion that 'the involvement of secondary stakeholders is limited, and they can affect, or be affected by, various activities of the organizations". Hence, the uniqueness of the NOGI lies in the existence of the various sub-groups of secondary stakeholders within the primary stakeholder i.e. the community.

Data gathered suggested that resulting from decades of perceived neglect by the OPCs and the Nigerian government, communities in the NDRN have repeatedly staged protests to express their concerns. This, as in most cases, has resulted in conflicts and violence between the community and the other stakeholders within the NOGI. Such dramatic action has further brought division within the community itself. The division within the community is as a result of the diverse interest of the various sub-groups of secondary stakeholders who believed that their appointed community representatives (i.e. the community rulers and/or the council of chiefs) do not 
represent their interest appropriately with other stakeholders within the NOGI. This is also consistent with Okeke-Ogbuafor et al's (2016) finding that the community people do not see their community representatives to be representing their interest appropriately. Research participants further asserted that these sub-groups of secondary stakeholders now use this medium to attract the attention of other stakeholders within the NOGI in order to make their interest(s) known. The after-effect of this is the emergence of different sub-groups of secondary stakeholders within the community.

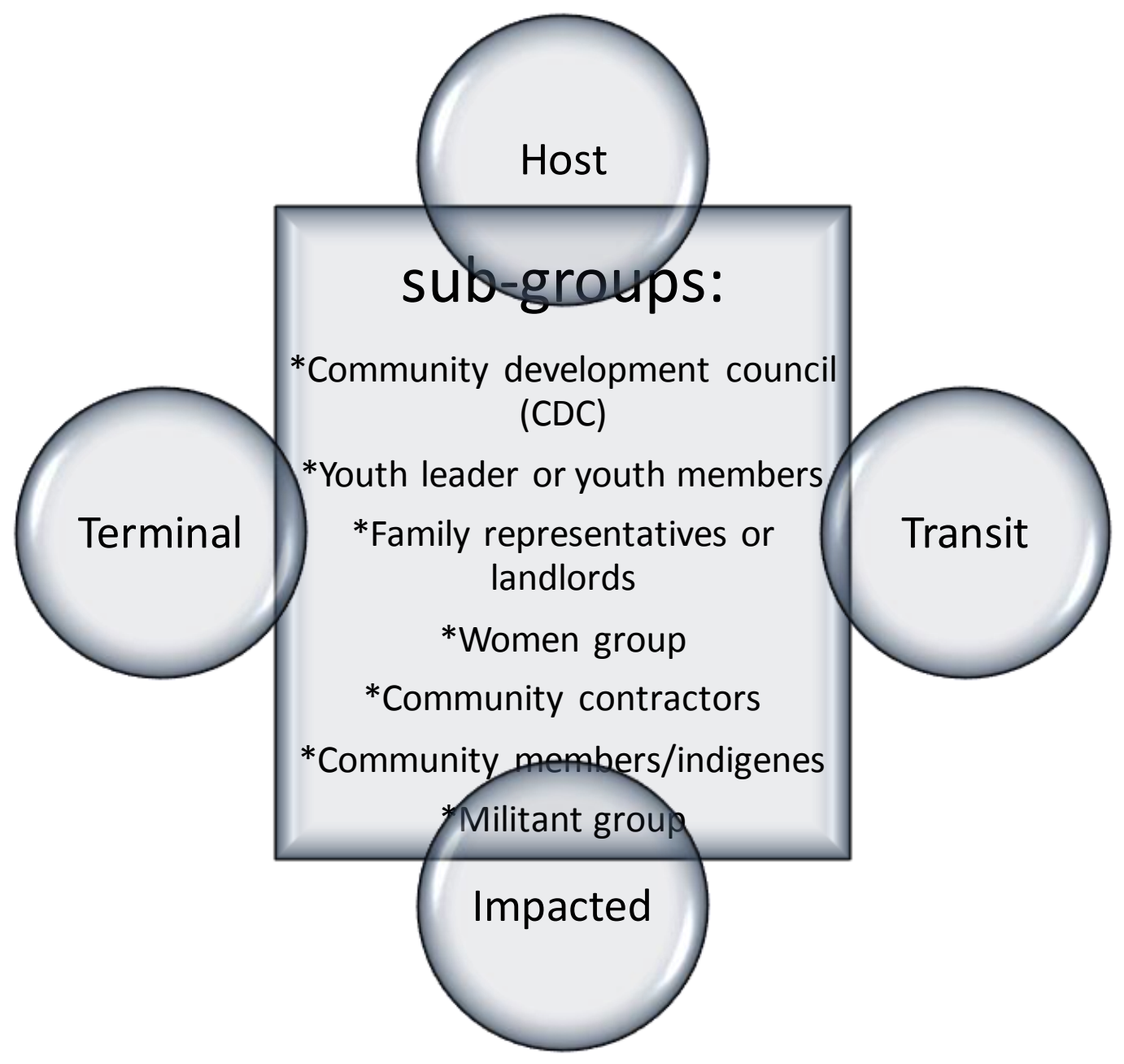

Figure 4. Types of Community in the Niger Delta Region (author generated)

Therefore, deciding which of these sub-groups of secondary stakeholders that attention should be given to during decision-making becomes an issue for other stakeholders. In order to capture the concerns of all these sub-groups of secondary stakeholders and effectively manage their interest while avoiding conflicts among them (Robinson 2005), it becomes imperative to understand how communities within the NDRN operate.

\subsection{Complexity within the Community Group}

The research participants asserted that the desire of the various sub-groups of secondary stakeholders within the community to express their concerns and make their interest known brought about complexity within the community. Complexity within this context is referred to a situation in which the various sub-groups of secondary stakeholders within the community become relevant and are deemed fit for direct relations with the other key stakeholders within the NOGI, as opposed to going through their community (Vandekerckhove and Dentchev, 2005; Rowley 1997; Freeman and Evan 1990). Research participants stated that the community has always been known to be of one voice through the "community ruler" (i.e. the King and his council of chiefs) until a few decades ago when various sub-groups of stakeholders within the community felt there was an ongoing act of misrepresentation and neglect on the part of the community ruler. They explained the transition in power and influence of the community ruler under the following headings; pre-colonial era, colonial era and post-colonial era. 


\subsubsection{Community during the Pre-Colonial Era}

Research participants asserted that during the pre-colonial era prior to the presence of the colonial masters i.e. the British rule, community operated as a single entity where community members were subject to the command and direction of the community ruler. They stated that the community ruler acquired his title through inheritance or through appointment by a council of elders from the community. The community ruler was by default and/or nature always a man. This could be attributed to the belief (i.e. culture) of the people that women are meant to be submissive to men. Each community shares the same belief and ideologies. However, research participants concluded that even though the community ruler influences and commands respect from the community people, he lacks any formal political power. Figure 6 suggests the potential community structure during the pre-colonial era as explained by the research participants.

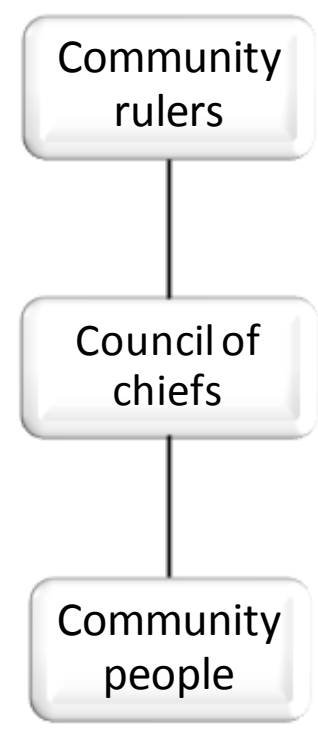

Figure 6. Potential Community Structure during the Pre-Colonial Era (author generated)

\subsubsection{Community during the Colonial Era}

Research participants stated that upon the arrival of the "colonial masters", the community rulers were seen as important in achieving effective administration. They acted as the intermediary between the colonial masters and their respective communities. However, the research participants asserted that the introduction of a legislative council with some elected members by the colonial masters reduced the importance placed on community rulers. This is consistent with Diebah et al's (2003) assertion that community rulers are perceived to hold a symbolic role during the colonial era. However, research participants argued that community members remained subject to the command and direction of the community ruler. Figure 7 suggests the potential community structure during the colonial era as explained by the research participants

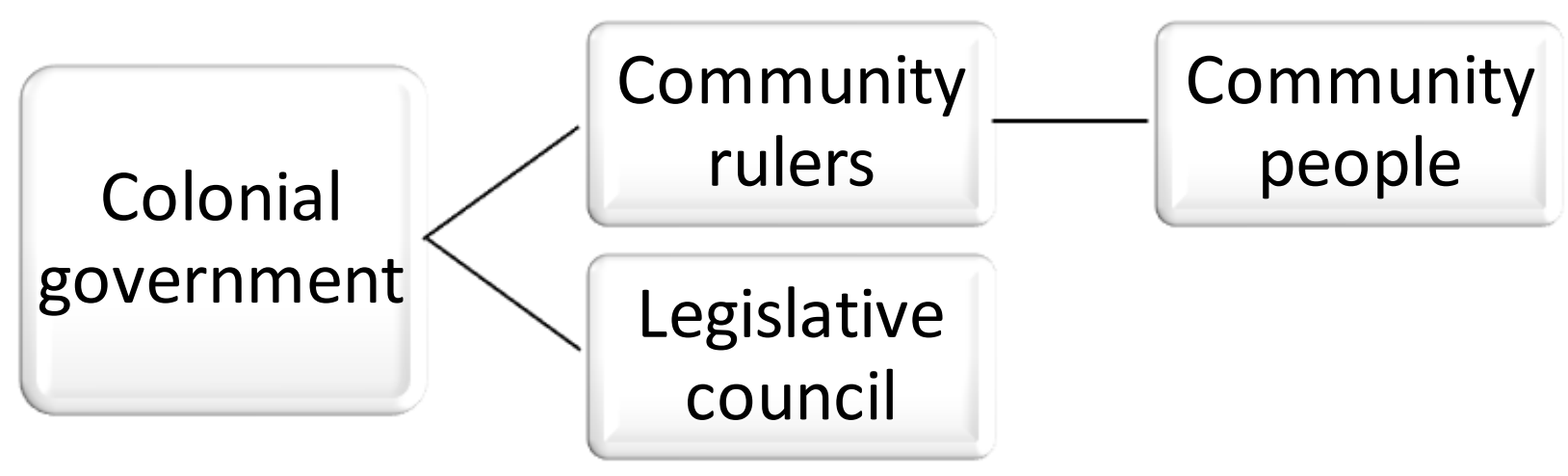

Figure 7. Potential Community Structure during the Colonial Era (author generated) 


\subsubsection{Community during the Post-Colonial Era}

Research participants asserted that with independence in 1960 and the introduction of a formal government (i.e. democratic government) in place, the status of the community leader regained its importance as the government evidenced interest in the succession of community rulers. They stated that community rulers in the post-colonial era are highly respected in many communities, and have considerable economic and political influence as shown in figure 8. Research participants argued that community rulers exercise authority over their communities because they have been appointed and trusted to do so in the interest of the people as opposed to exercising power over their communities. This stand-point illustrates the difference between power and authority of the community rulers. "Power has been defined as the ability to induce others to perform tasks or carry out directives that they would not ordinarily do" (McKinney and Howard, 1998: 34). Likewise, power is referred to as the capacity to get people do something the way one wants it done (Pfeffer and Salancik, 2003). These definitions suggest that power is informal and it makes use of force in order to get things done (Grimes, 1978). However, authority has been defined by Barnard (1968: 161) as "the character of a communication in a formal organisation by virtue of which it is accepted by a contributor to, or member of, the organisation as governing the action he contributes". This perspective suggests that an individual only exercises authority within agreed boundaries that are well established in either or both of the people's beliefs, religious practice, or law. Hence, authority is considered legitimate (Grimes, 1978).

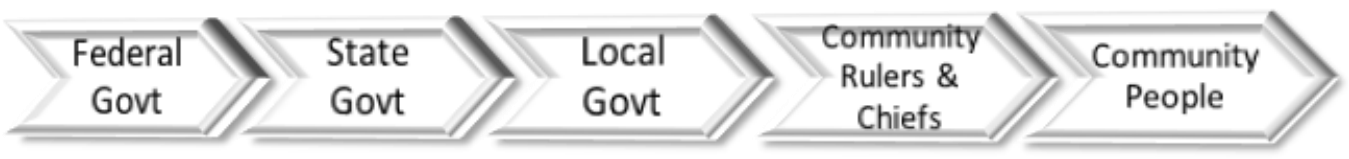

Figure 8. Potential Community Structure during the Post-Colonial Era (author generated)

Arguably, community rulers play significant roles in acting as intermediaries between the community members and the outside world (e.g. the government and investors). They also act for and represent the community identity, provide safety and resolve conflicts among community members. A major reason for a community ruler's influence may have been attributed to the inability of most community members to communicate in the official English language, so the community ruler served as the spokesperson and interpreter (Miles 1993). However, present day community members are more exposed to outside influences and are also more educated than their predecessors.

The community rulers seem to have lost the trust previously put in them by their community members, thus resulting in the emergence of various sub-groups of secondary stakeholders within the community expressing their concerns to other stakeholders within the NOGI in various ways. These sub-groups of secondary stakeholders believe that their interest is no longer served by the community spokesperson (i.e. community ruler). As a result, these sub-groups of secondary stakeholders may employ any available strategy (e.g. conflicts and violence) in order to get the attention of other stakeholders within the NOGI so as to ensure the fulfilment of their respective individual interest, thus causing and making it difficult for other key stakeholders such as the OPCs and the Nigerian government to effectively manage the community as a single entity. This has prompted the need for the identification of the various sub-groups of secondary stakeholders in the community within the NOGI context.

\subsection{Defining Who the Sub-groups of Secondary Stakeholder Are}

The decision in respect of which stakeholder should be recognised or not depends on the stakeholder's importance (Salam and Noguchi, 2006). Grimble et al (1995) argued that individuals or groups of individuals who are likely to affect the functioning of an organisation or a project given their resources, interests, and influence need to be included. This is consistent with Mitchell et al's (1997) assertion that stakeholder importance is a function of their legitimacy, power and urgency. Even though the community rulers \& their chiefs are perceived as the community spokesperson and representative, the research participants identified seven sub-groups of secondary stakeholders that existed within the community stakeholder group. Bryson et al. (2002) asserted that an inclusive view of stakeholders is important, while Clarkson and Deck (1994) concluded 
that ignoring an important stakeholder may result in poor strategy formulation and thus, an organisation's failure. Therefore, the effort regarding identification and definition given to the various sub-groups of secondary stakeholders within the community has been based on their legitimacy, power and urgency as explained by the research participants. These sub-groups came into play when the research participants were asked to identify the various secondary players within the community outside the community rulers and their chiefs.

1) Community development council (CDC): A government initiative to organise grassroot community programs that bridge the gap between the community and the government.

2) Youth leader or youth members: This consists of peer group (i.e. 35 years and below) within a community and specifically consist of the community youths with a leader who represents and inspires their interest.

3) Family representatives or landlords: A representative from each family within a community forming an association in order to have a common say when it comes to issues such as sale of land.

4) Women's group: This is an association of community women who come together to discuss issues (i.e. non-domestic) that impact on their existence as a result of an OPC presence in the community.

5) Community contractors: These are community members (i.e. indigenes) to who contracts are awarded by an OPC by way of community development.

6) Community members/indigenes: These are the general members (i.e. indigenes) of the community who do not belong to any of the aforementioned groups. It includes both men and women, young and old.

7) Militia group: Armed groups that came into existence under the umbrella that the OPC neglect the communities.

\subsection{Interest $(s)$ of Sub-groups of Secondary Stakeholder}

Research participants further identify the various interest(s) and impact(s) of the various sub-groups of secondary stakeholders within the NDRN. They argued that these interests are often dictated by their needs or wants. The importance of these needs or wants varies across the sub-groups of secondary stakeholders within the community. Hence, necessitating the need to identify and assess the interest(s) of these sub-groups of secondary stakeholders and their respective impact on the NOGI as shown in table 4.

Table 4. Interest(s) and Impact(s) of Sub-groups (Research participants' responses)

\begin{tabular}{|c|c|c|}
\hline $\begin{array}{l}\text { Sub-groups of Secondary } \\
\text { Stakeholders }\end{array}$ & Interest & Impact \\
\hline $\begin{array}{l}\text { Community Development } \\
\text { Council }\end{array}$ & $\begin{array}{l}\text { Community development e.g. providing } \\
\text { amenities, good road networks and } \\
\text { ensuring environmental rights and } \\
\text { protection }\end{array}$ & $\begin{array}{l}\text { Can influence the negotiation process and } \\
\text { terms between the OPC and HC either } \\
\text { positively or negatively. }\end{array}$ \\
\hline Youth leaders and or members & Employment and empowerment & $\begin{array}{l}\text { Halt oil and gas operations and activities } \\
\text { through their violence and conflict agitations }\end{array}$ \\
\hline Family representatives & $\begin{array}{l}\text { Demand for compensation for the } \\
\text { ecological damage and loss of property } \\
\text { e.g. land }\end{array}$ & $\begin{array}{l}\text { Can cause limited disruption to oil and gas } \\
\text { activities. However, it can degenerate into } \\
\text { violence if supported by any other sub-group } \\
\text { of stakeholder. }\end{array}$ \\
\hline Women group & $\begin{array}{l}\text { General community welfare e.g. social } \\
\text { amenities and rights protection }\end{array}$ & $\begin{array}{l}\text { Staging of protest within the community to } \\
\text { express their grievances. However, this often } \\
\text { degenerate into violence if not attended to } \\
\text { promptly. }\end{array}$ \\
\hline Community contractors & Seek contracts from OPCs & $\begin{array}{l}\text { Staging of protest within the community to } \\
\text { express their grie vances. However, it can } \\
\text { degenerate into violence if supported by any } \\
\text { other sub-group of stakeholder. }\end{array}$ \\
\hline $\begin{array}{l}\text { Community } \\
\text { indigenes }\end{array}$ & $\begin{array}{l}\text { General community welfare e.g. } \\
\text { environmental concerns and provision of } \\
\text { amenities and facilities }\end{array}$ & $\begin{array}{l}\text { Can cause a major disruption to oil and gas } \\
\text { activities. }\end{array}$ \\
\hline Militia groups & Seek access to \& control of resources. & $\begin{array}{l}\text { Destruction of oil and gas facilities. } \\
\text { Abduction/ kidnapping of indigenous and } \\
\text { expatriate staff for ransom taking and } \\
\text { economic crimes such as pipeline } \\
\text { vandalisation, sea piracy and oil pilferage }\end{array}$ \\
\hline
\end{tabular}

\section{Conclusion}

Steps need to be taken by the OPCs and the Nigerian government to ensure that they can engage with the wider sub-groups of secondary stakeholders and not just the usual community group spokespeople who mainly represent their own interests. 


\subsection{Implication for Policy Makers}

Policy makers have to be aware of the importance of the different sub-groups of secondary stakeholders within the community. Their respective interest and level of influence must be taken into consideration in the policy making process because they can either promote or hinder policy implementation. Walt (1994) argued that policy makers should seek support and involve different interest groups in policy formulation and implementation. Likewise, Kumar et al (2016: 38) asserted that the involvement of these groups of stakeholders is limited, yet "they can affect, or by affected by, various activities of the organizations". Stakeholder identification from the policy makers' point of view provides a framework which assists policy makers in the analysis of community group influence and interest on policy. It considers the impact of the various sub-groups of secondary stakeholders within the community has on decision making, policy process and their interrelations. Hence, the interest(s) of the various sub-groups of secondary stakeholders should be taken into consideration during policy formulation.

\subsection{Implication for Management}

Stakeholder approaches to management suggest that when the interests and influence of various individuals or groups within and outside an organisation are taken into consideration, the organisation goals and objectives will be achieved. Preston and Sapienza (1991) argued that when the needs of the primary stakeholders, for example the general public of which the community is one are met, the company stands to benefit as well. A stakeholder approach to management that supports the influence and interest of individuals and/or groups should be taken on board while planning and making of strategic decisions in order to manage change, and evaluate opportunities and threats (Mason and Mitroff, 1981). Likewise, Freeman's (1984) stand-point of a stakeholder is that stakeholders can influence the achievement of an organisation's objectives. This therefore suggests that OPC management are to put in place strategies that will neutralise or encourage stakeholders, depending on their desire to oppose or support the objectives of the organisation. Hence, the identification of various sub-groups of secondary stakeholders within the Community stakeholder group will give the OPC management opportunity to acquire appropriate and adequate knowledge about the relevant actors within the community so as to take into consideration their intentions, behaviour, interests, agenda, and the resources they can bring or their influence (Brugha and Varvasovsky, 2000). In addition, the OPC should make effort in engaging and communicating with all the various sub-groups of secondary stakeholders in their community of operations in addition to the traditional rulers and their chiefs. Furthermore, it suggests the different level of importance that should be accorded to each sub-group of secondary stakeholders within the community itself. More so, it will help identify and aid understanding of the likely conflicting interests among the various sub-groups of secondary stakeholders (Friedman and Miles, 2006; Prell et al., 2007).

\section{References}

Achterkamp, M. C., \& Vos, J. F. (2006). A framework for making sense of sustainable innovation through stakeholder involvement. International Journal of Environmental Technology and Management, 6(6), 525-538. https://doi.org/10.1504/IJETM.2006.011895

Achterkamp, M. C., \& Vos, J. F. (2008). Investigating the use of the stakeholder notion in project management literature, a meta-analysis. International Journal of Project Management, 26(7), 749-757. https://doi.org/10.1016/j.jproman.2007.10.001

Agle, B. R., Mitchell, R. K., \& Sonnenfeld, J. A. (1999). Who matters to ceos? an investigation of stakeholder attributes and salience, corpate performance, and ceo values. Academy of Management Journal, 42(5), 507-525. https://doi.org/10.2307/256973

Agrawal, A., \& Gibson, C. C. (1999). Enchantment and disenchantment: The role of community in natural resource conservation. World Development, 27(4), 629-649. https://doi.org/10.1016/S0305-750X(98)00161-2

Ahlstedt, L., \& Jahnukainen, I. (1971). The organization of a firm as a management system for cooperation. Weilin.

AKPOMUVIE, O. (2011). Tragedy of commons: Analysis of oil spillage, gas flaring and sustainable development of the niger delta of nigeria. Journal of Sustainable Development, 4(2), 200.

Alkhafaji, A. F. (1989). A stakeholder approach to corporate governance: Managing in a dynamic environment Quorum Books New York.

Allen, J., \& Hamnett, C. (1995). A shrinking world. Global Unevenness and Inequality. 
Andersen, R. (2005). The farmers' rights project-background study 2: Results from an international stakeholder survey on farmers' rights.

Anderson, B. R. (1983). Old state, new society: Indonesia's new order in comparative historical perspective. The Journal of Asian Studies, 42(03), 477-496. https://doi.org/10.2307/2055514

Ansell, C., \& Gash, A. (2012). Stewards, mediators, and catalysts: Toward a model of collaborative leadership1 . The Innovation Journal, 17(1), 2.

Asuni, J. B. (2009). Blood oil in the niger delta United States Institute of Peace Washington, DC.

Atkin, B., \& Skitmore, M. (2008). Editorial: Stakeholder management in construction. Construction Management and Economics, 26(6), 549-552. https://doi.org/10.1080/01446190802142405

Ballejos, L. C., \& Montagna, J. M. (2008). Method for stakeholder identification in interorganizational environments. Requirements Engineering, 13(4), 281-297. https://doi.org/10.1007/s00766-008-0069-1

Barnard, C. I. (1968). The functions of the executive Harvard university press.

Bell, C., \& Newby, H. (1971). Community studies: An introduction to the the local community Allen and Unwin.

Berman, S. L., Wicks, A. C., Kotha, S., \& Jones, T. M. (1999). Does stakeholder orientation matter? the relationship between stakeholder management models and firm financial performance. Academy of Management Journal, 42(5), 488-506. https://doi.org/10.2307/256972

Boddy, D., \& Paton, R. (2004). Responding to competing narratives: Lessons for project managers. International Journal of Project Management, 22(3), 225-233. https://doi.org/10.1016/j.ijproman.2003.07.001

Boesso, G., \& Kumar, K. (2016). Examining the association between stakeholder culture, stakeholder salience and stakeholder engagement activities: An empirical study. Management Decision, 54(4), 815-831. https://doi.org/10.1108/MD-06-2015-0245

Bosse, D. A., Phillips, R. A., \& Harrison, J. S. (2009). Stakeholders, reciprocity, and firm performance. Strategic Management Journal, 30(4), 447-456. https://doi.org/10.1002/smj.743

Bourne, L., \& Walker, D. H. (2006). Using a visualising tool to study stakeholder influence-two australian examples. Journal of Project Management, 37(1), 5-21.

Bowen, G. A. (2008). Naturalistic inquiry and the saturation concept: A research note. Qualitative Research, 8(1), 137-152. https://doi.org/10.1177/1468794107085301

Bowie, N. (1988). The moral obligations of multinational corporations. Problems of International Justice, 97 , 113.

Brenner, S. N. (1995). Stakeholder theory of the firm: Its consistency with current management techniques. Understanding Stakeholder Thinking, 75, 96.

Brenner, S. N., \& Cochran, P. (1993). The stakeholder theory of the firm and organizational decision making: Some propositions and a model. Proceedings of the Fourth Annual Meeting of the International Association for Business and Society, 205-210. https://doi.org/10.5840/iabsproc1993431

Brugha, R., \& Varvasovszky, Z. (2000). Stakeholder analysis: A review. Health Policy and Planning, 15(3), 239-246. https://doi.org/10.1093/heapol/15.3.239

Buchholz, R. A., \& Rosenthal, S. B. (2005). Toward a contemporary conceptual framework for stakeholder theory. Journal of Business Ethics, 58(1-3), 137-148. https://doi.org/10.1007/s10551-005-1393-8

Bundy, J., Shropshire, C., \& Buchholtz, A. K. (2013). Strategic cognition and issue salience: Toward an explanation of firm responsiveness to stakeholder concerns. Academy of Management Review, 38(3), 352-376. https://doi.org/10.5465/amr.2011.0179

Carroll, A. B., \& Buchholtz, A. K. (1996). Ethics and stakeholder management. Cincinnati: South-Western,

Carroll, A. B., \& Buchholtz, A. K. (2011). Business \& society: Ethics and stakeholder management CengageBrain. com.

Cater, J., \& Jones, T. (1989). Social geography: An introduction to contemporary issues Arnold.

Chapleo, C., \& Simms, C. (2010). Stakeholder analysis in higher education: A case study of the university of portsmouth. Perspectives, 14(1), 12-20. https://doi.org/10.1080/13603100903458034

Chevalier, J. M., \& Buckles, D. J. (2008). SAS2 social analysis systems: A guide to collaborative inquiry and 
social engagement IDRC.

Choi, J. (1999). An investigation of the initial voluntary environmental disclosures made in korean se mi-annual financial reports. Pacific Accounting Review, 11(1), 73-102.

Clarkson, M. B. (1994). A risk based model of stakeholder theory. Proceedings of the Second Toronto Conference on Stakeholder Theory, 18-19.

Clarkson, M. E. (1995). A stakeholder framework for analyzing and evaluating corporate social performance. Academy of Management Review, 20(1), 92-117.

Clarkson, M., \& Deck, M. (1994). Bankruptcies, boards of directors, and officers: Testing stakeholder theory. Proceedings of the Second Toronto Conference on Stakeholder Theory.

Cleland, D. I. (1986). Project stakeholder management Wiley Online Library.

Cleland, D. I. (1989). Strategic issues in project management.

Colgan, J. D. (2014). The emperor has no clothes: The limits of OPEC in the global oil market. International Organization, 68(03), 599-632. https://doi.org/10.1017/S0020818313000489

Cormier, D., \& Magnan, M. (2003). Environmental reporting management: A continental european perspective. Journal of Accounting and Public Policy, 22 (1), 43-62. https://doi.org/10.1016/S0278-4254(02)00085-6

Cornell, B., \& Shapiro, A. C. (1987). Corporate stakeholders and corporate finance. Financial Management, 5-14. https://doi.org/10.2307/3665543

Couillard, J., Garon, S., \& Riznic, J. (2009). The logical framework approach-millennium. Project Management Journal, 40(4), 31-44. https://doi.org/10.1002/pmj.20117

Coyne, I. T. (1997). Sampling in qualitative research. purposeful and theoretical sampling; merging or clear boundaries? Journal of Advanced Nursing, 26(3), 623-630. https://doi.org/10.1046/j.1365-2648.1997.t01-25-00999.x

Crow, G., \& Allen, G. (1994). Community life: An introduction to local social relations Harvester-Wheatsheaf.

Cummings, L., Patel, C., Cummings, L., \& Patel, C. (2009). Chapter 2 stakeholder literature review. Managerial attitudes toward a stakeholder prominence within a southeast asia context (pp. 17-51) Emerald Group Publishing Limited. https://doi.org/10.1108/S1479-3512(2009)0000019006

Dahl, R. A. (1957). The concept of power. Behavioral Science, 2(3), 201-215. https://doi.org/10.1002/bs.3830020303

Delanty, G. (2003). Community: Key ideas. London: Rout-Ledge.

Diallo, A., \& Thuillier, D. (2005). The success of international development projects, trust and communication: An african perspective. International Journal of Project Management, 23(3), $237-252$. https://doi.org/10.1016/j.ijproman.2004.10.002

Dinsmore, P. C. (1990). Ideas, guidelines and techniques for applying project management solutions in the general business arena: Lessons for executives. International Journal of Project Management, 8(1), 33-38. https://doi.org/10.1016/0263-7863(90)90006-W

Donaldson, T., \& Preston, L. E. (1995). The stakeholder theory of the corporation: Concepts, evidence, and implications. Academy of Management Review, 20(1), 65-91.

Driscoll, C., \& Starik, M. (2004). The primordial stakeholder: Advancing the conceptual consideration of stakeholder status for the natural environment. Journal of Business Ethics, 49(1), 55-73. https://doi.org/10.1023/B:BUSI.0000013852.62017.0e

Durkheim (1964). The division of labour in society, translated by George Simpson. Free Press, New York.

Dutton, J. E., \& Jackson, S. E. (1987). Categorizing strategic issues: Links to organizational action. Academy of Management Review, 12(1), 76-90.

Edomah, N., Foulds, C., \& Jones, A. (2016). Energy transitions in nigeria: The evolution of energy infrastructure provision (1800-2015). Energies, 9(7), 484. https://doi.org/10.3390/en9070484

Edum-Fotwe, F. T., \& Price, A. D. (2009). A social ontology for appraising sustainability of construction projects and developments. International Journal of Project Management, 27(4), 313-322. https://doi.org/10.1016/j.ijproman.2008.04.003 
Edward, F. R., \& Evan, W. M. (1991). Corporate governance: A stakeholder interpretation. Journal of Behavioral Economics, 19(4), 337-359. https://doi.org/10.1016/0090-5720(90)90022-Y

El-Gohary, N. M., Osman, H., \& El-Diraby, T. E. (2006). Stakeholder management for public private partnerships. International Journal of Project Management, 24(7), 595-604. https://doi.org/10.1016/j.ijproman.2006.07.009

Emoyan, O. (2008). The oil and gas industry and the niger delta: Implications for the environment. Journal of Applied Sciences and Environmental Management, 12(3).

Etu-Efeotor, J. (1995). Anticipation and management of crisis: A case study. Perspectives on the Nigerian Oil Industry, Edited by Kayode Soremekun.Lagos: Amkra Books,

Eweje, G. (2006). The role of MNEs in community development initiatives in developing countries corporate social responsibility at work in nigeria and south africa. Business \& Society, 45(2), 93-129. https://doi.org/10.1177/0007650305285394

Eweje, G. (2007). Strategic partnerships between MNEs and civil society: The post-WSSD perspectives. Sustainable Development, 15(1), 15-27. https://doi.org/10.1002/sd.295

Farrance, C., Tsofliou, F., \& Clark, C. (2016). Adherence to community based group exercise interventions for older people: A mixed-methods systematic review. Preventive Medicine, 87, 155-166. https://doi.org/10.1016/j.ypmed.2016.02.037

Fassin, Y. (2009). The stakeholder model refined. Journal of Business Ethics, 84(1), 113-135. https://doi.org/10.1007/s10551-008-9677-4

Freeman, R. E. (1988). A stakeholder theory of the modern corporation. Perspectives in Bus Ethics Sie 3E, 144.

Freeman, R. E. (1994). The politics of stakeholder theory: Some future directions. Business Ethics Quarterly, 409-421. https://doi.org/10.2307/3857340

Freeman, R. E., \& Evan, W. M. (1990). Corporate governance: A stakeholder interpretation. Journal of Behavioral Economics, 19(4), 337-359. https://doi.org/10.1016/0090-5720(90)90022-Y

Freeman, R. E., \& Gilbert, D. R. (1987). Managing stakeholder relationships. Business and Society: Dimensions of Conflict and Cooperation, 397, 423.

Freeman, R. E., \& Phillips, R. A. (2002). Stakeholder theory: A libertarian defense. Business Ethics Quarterly, 12(03), 331-349. https://doi.org/10.2307/3858020

French, D., \& Saward, H. (1975). Dictionary of management International Publications Service.

Friedman, A. L., \& Miles, S. (2002). Developing stakeholder theory. Journal of Management Studies, 39(1), 1-21. https://doi.org/10.1111/1467-6486.00280

Friedman, A. L., \& Miles, S. (2006). Stakeholders: Theory and practice Oxford University Press on Demand.

Frooman, J. (1999). Stakeholder influence strategies. Academy of Management Review, 191-205.

Frynas, J. G. (2000). Oil in nigeria: Conflict and litigation between oil companies and village communities LIT Verlag Münster.

Frynas, J. G. (2001). Corporate and state responses to anti-oil protests in the niger delta. [gave insight into the nigeria oil industry and evolution of anti-protest in the Niger delta of Nigeria. Considers the creation of nnpc and the promulgation of the land use act of 1978 as a major problem which redefined the legal position on land ownership in nigeria by vesting the ownership of all land within a state. this renders the community no longer having the right to question the entry of oil company.] African Affairs, 100(398), 27-54. https://doi.org/10.1093/afraf/100.398.27

Frynas, J. G. (2005). The false developmental promise of corporate social responsibility: Evidence from multinational oil companies. International Affairs, 81(3), 581-598. https://doi.org/10.1111/j.1468-2346.2005.00470.x

Frynas, J. G. (2009). Beyond corporate social responsibility. Oil Multinationals and Social Challenges. https://doi.org/10.1017/CBO9780511581540

Gandy, M. (2002). Between borinquen and the barrio: Environmental justice and new york city's puerto rican community, 1969-1972. Antipode, 34(4), 730-761. https://doi.org/10.1111/1467-8330.00267

García-Sánchez, I., Frías-Aceituno, J., \& Rodríguez-Domínguez, L. (2013). Determinants of corporate social 
disclosure in spanish local governments. Journal of Cleaner Production, 39, 60-72. https://doi.org/10.1016/j.jclepro.2012.08.037

Gibson, K. (2000). The moral basis of stakeholder theory. Journal of Business Ethics, 26(3), 245-257. https://doi.org/10.1023/A:1006110106408

Goodpaster, K. E. (1991). Business ethics and stakeholder analysis. Business Ethics Quarterly, 53-73. https://doi.org/10.2307/3857592

Grimble, R., \& Wellard, K. (1997). Stakeholder methodologies in natural resource management: A review of principles, contexts, experiences and opportunities. Agricultural Systems, 55(2), 173-193. https://doi.org/10.1016/S0308-521X(97)00006-1

Grimble, R., Chan, M., Aglionby, J., \& Quan, J. (1995). Trees and trade-offs: A stakeholder approach to natural resource management. Gatekeeper Series-Sustainable Agriculture Programme, International Institute for Environment and Development (United Kingdom).

Grimes, A. J. (1978). Authority, power, influence and social control: A theoretical synthesis. Academy of Management Review, 3(4), 724-735. https://doi.org/10.2307/257928

Gusfield, J. R. (1975). Community: A critical response Harper \& Row New York.

Harrison, J. S., \& Freeman, R. E. (1999). Stakeholders, social responsibility, and performance: Empirical evidence and theoretical perspectives. Academy of Management Journal, 42(5), 479-485. https://doi.org/10.2307/256971

Harrison, J. S., Bosse, D. A., \& Phillips, R. A. (2010). Managing for stakeholders, stakeholder utility functions, and competitive advantage. Strategic Management Journal, 31 (1), 58-74. https://doi.org/10.1002/smj.801

Hennink, M., Hutter, I., \& Bailey, A. (2010). Qualitative research methods Sage.

Henriques, I., \& Sadorsky, P. (1999). The relationship between environmental commitment and managerial perceptions of stakeholder importance. Academy of Management Journal, 42(1), 87-99. https://doi.org/10.2307/256876

Hill, C. W., \& Jones, T. M. (1992). Stakeholder-agency theory. Journal of Management Studies, 29(2), 131-154. https://doi.org/10.1111/j.1467-6486.1992.tb00657.x

Hillman, A. J., \& Keim, G. D. (2001). Shareholder value, stakeholder management, and social issues: What's the bottom line? Strategic Management Journal, 22(2), 125-139. https://doi.org/10.1002/1097-0266(200101)22:2<125::AID-SMJ150>3.0.CO;2-H

Idemudia, U. (2007). Community perceptions and expectations: Reinventing the wheels of corporate social responsibility practices in the nigerian oil industry. Business and Society Review, 112(3), 369-405. https://doi.org/10.1111/j.1467-8594.2007.00301.x

Idemudia, U. (2009). Assessing corporate-community involvement strategies in the nigerian oil industry: An empirical analysis. Resources Policy, 34(3), 133-141.https://doi.org/10.1016/j.resourpol.2009.01.002

Idemudia, U. (2010). Rethinking the role of corporate social responsibility in the nigerian oil conflict: The limits of CSR. Journal of International Development, 22(7), 833-845. https://doi.org/10.1002/jid.1644

Idemudia, U., \& Ite, U. E. (2006). Corporate-community relations in nigeria's oil industry: Challenges and imperatives. Corporate Social Responsibility and Environmental Management, 13(4), 194-206. https://doi.org/10.1002/csr.101

Ikelegbe, A. (2001). Civil society, oil and conflict in the niger delta region of nigeria: Ramifications of civil society for a regional resource struggle. The Journal of Modern African Studies, 39(03), 437-469. https://doi.org/10.1017/S0022278X01003676

Javed, T., \& Durrani, Q. S. (2006). Managing geographically distributed clients throughout the project management life cycle. Project Management Quarterly, 37(5), 76.

Jepsen, A. L., \& Eskerod, P. (2009). Stakeholder analysis in projects: Challenges in using current guidelines in the real world. International Journal of Project Management, 27(4), 335-343. https://doi.org/10.1016/j.jproman.2008.04.002

Jonker, J., \& Foster, D. (2002). Stakeholder excellence? framing the evolution and complexity of a stakeholder perspective of the firm. Corporate Social Responsibility and Environmental Management, 9(4), 187-195. https://doi.org/10.1002/csr.23 
Kapoor, I. (2002). The devil's in the theory: A critical assessment of robert chambers' work on participatory development. Third World Quarterly, 23(1), 101-117. https://doi.org/10.1080/01436590220108199

Khan, S. A. (1994). Nigeria: The political economy of oil.

Koster, R., Baccar, K., \& Lemelin, R. H. (2012). Moving from research ON, to research WITH and FOR indigenous communities: A critical reflection on community-based participatory research. The Canadian Geographer/Le Géographe Canadien, 56(2), 195-210. https://doi.org/10.1111/j.1541-0064.2012.00428.x

Kruckeberg, D., \& Starck, K. (1988). Public relations and community: A reconstructed theory Praeger Publishers.

Langtry, B. (2009). Stakeholders and the moral responsibilities of business. Business Ethics Quarterly, 4(4), 431-443. https://doi.org/10.2307/3857342

Laplume, A. O., Sonpar, K., \& Litz, R. A. (2008). Stakeholder theory: Reviewing a theory that moves us. Journal of Management, 34(6), 1152-1189. https://doi.org/10.1177/0149206308324322

Mackenzie, A. F. D., \& Dalby, S. (2003). Moving mountains: Community and resistance in the isle of harris, scotland, and cape breton, canada. Antipode, 35(2), 309-333. https://doi.org/10.1111/1467-8330.00325

Magness, V. (2008). Who are the stakeholders now? an empirical examination of the mitchell, agle, and wood theory of stakeholder salience. Journal of Business Ethics, 83(2), 177-192. https://doi.org/10.1007/s10551-007-9610-2

Manowong, E., \& Ogunlana, S. (2010). Strategies and tactics for managing construction stakeholders. Construction Stakeholder Management, 121-137.

Margolis, J. D., \& Walsh, J. P. (2003). Misery loves companies: Rethinking social initiatives by business. Administrative Science Quarterly, 48(2), 268-305. https://doi.org/10.2307/3556659

Mason, R. O., \& Mitroff, I. I. (1981). Challenging strategic planning assumptions: Theory, cases, and techniques John Wiley \& Sons Inc.

McElroy, B., \& Mills, C. (2000). Managing stakeholders. Turner, RJ \& Simister, SJ (Eds.) Gower Handbook of Project Management. Gower, Aldershot.

McKinney, J. B., \& Howard, L. C. (1998). Public administration: Balancing power and accountability ABC-CLIO.

Miles, W. F. (1993). Colonial hausa idioms: Toward a west african ethno-ethnohistory. African Studies Review, 36(2), 11-30. https://doi.org/10.2307/524731

Minoja, M. (2012). Stakeholder management theory, firm strategy, and ambidexterity. Journal of Business Ethics, 109(1), 67-82. https://doi.org/10.1007/s10551-012-1380-9

Mitchell, R. K., Agle, B. R., \& Wood, D. J. (1997). Toward a theory of stakeholder identification and salience: Defining the principle of who and what really counts. Academy of Management Review, 853-886.

Mitchell, R. K., Agle, B. R., Chrisman, J. J., \& Spence, L. J. (2011). Toward a theory of stakeholder salience in family firms. Business Ethics Quarterly, 21(02), 235-255. https://doi.org/10.5840/beq201121215

Mulrennan, M. E., Mark, R., \& Scott, C. H. (2012). Revamping community-based conservation through participatory research. The Canadian Geographer/Le Géographe Canadien, 56(2), 243-259. https://doi.org/10.1111/j.1541-0064.2012.00415.x

Naanen, B. (2004). The political economy of oil and violence in the niger delta. ACAS Bulletin, 68(Fall), 4.

Näsi, J. (1995). Understanding stakeholder thinking LSR-Publications.

Nevan, W. J. (1997). Time and budget: The twin imperatives of a project sponsor. International Journal of Project Management, 15(3), 181-186. https://doi.org/10.1016/S0263-7863(96)00059-2

Neville, B. A., Bell, S. J., \& Whitwell, G. (2004). Stakeholder salience revisited: Toward an actionable tool for the management of stakeholders. Academy of Management Proceedings, 2004(1), D1-D6. https://doi.org/10.5465/AMBPP.2004.13857458

Neville, B. A., Bell, S. J., \& Whitwell, G. J. (2011). Stakeholder salience revisited: Refining, redefining, and refueling an underdeveloped conceptual tool. Journal of Business Ethics, 102(3), 357-378. https://doi.org/10.1007/s10551-011-0818-9

NNPC. (2016). DEVELOPMENT OF Nigeria's oil industry. 
http://nnpcgroup.com/NNPCBusiness/BusinessInformation/OilGasinNigeria/DevelopmentoftheIndustry.asp $\mathrm{x}$

Obi, C. I. (2010). Oil extraction, dispossession, resistance, and conflict in nigeria's oil-rich niger delta. Canadian Journal of Development Studies/Revue Canadienne d'Études Du Développement, 30(1-2), 219-236.

Ogwo, O. E. (2016). Comparative assessment of the pre and post subsidy removal marketing performance of petroleum products marketers in nigeria. African Journal of Education, Science and Technology, 3(1), 116.

Oil and Gas. (2016). Lagos officially joins the league of Oil Producing States in Nigeria. http://www.ecofinagency.com/companies/1705-34403-lagos-officially-joins-the-league-of-oil-producing-sta tes-in-nigeria

Okeke-Ogbuafor, N., Gray, T., \& Stead, S. M. (2016). A comparative analysis of the role of traditional and modern community-based organizations in promoting community development in ogoniland, nigeria. Community Development Journal. https://doi.org/10.1093/cdj/bsw018

Okpamen, P. (Unknown). Environmental degradation in niger-delta and sustainable development in nigeria: Issues for consideration. Ishtiyaque Ahmed (India).

Olander, S. (2007). Stakeholder impact analysis in construction project management. Construction Management and Economics, 25(3), 277-287. https://doi.org/10.1080/01446190600879125

Olander, S., \& Landin, A. (2005). Evaluation of stakeholder influence in the implementation of construction projects. International Journal of Project Management, 23(4), 321-328. https://doi.org/10.1016/j.ijproman.2005.02.002

Olson, M. (2008). The rise and decline of nations: Economic growth, stagflation, and social rigidities Yale University Press.

Oluduro, O., \& Oluduro, O. F. (2012). Nigeria: In search of sustainable peace in the niger delta through the amnesty programme. Journal of Sustainable Development, 5(7), 48. https://doi.org/10.5539/jsd.v5n7p48

Omeje, K. C. (2006). High stakes and stakeholders: Oil conflict and security in nigeria Ashgate Publishing, Ltd.

Omofonmwan, S. I., \& Odia, L. O. (2009). Oil exploitation and conflict in the niger-delta region of nigeria. $J$ Hum Ecol, 26(1), 25-30.

Opukri, C., \& Ibaba, I. S. (2008). Oil induced environmental degradation and internal population displacement in the Nigeria's niger delta. Journal of Sustainable Development in Africa, 10(1), 173-193.

Oriola, T. B. (2016). Criminal resistance?: The politics of kidnapping oil workers Routledge.

Orubu, C. O., Odusola, A., \& Ehwarieme, W. (2004). The nigerian oil industry: Environmental diseconomies, management strategies and the need for community involvement. Journal of Human Ecology, 16(3), 203-214.

Oshwofasa, B. O., \& Anuta, D. E. (2012). Environmental degredation and oil industry activities in the niger-delta region. African Journal of Scientific Research, 9(1).

Osobajo, O. A., \& Moore, D. (2017). The B2Com Relationship: An Empirical Study of the Measure of Relationship Quality in a Business-to-Community Relationship. International Business Research, 10(7), 118-147. https://doi.org/10.5539/ibr.v10n7p118

Oyefusi, A. (2013). Micro-econometric analyses of some welfare effects of oil-availability in the niger delta region of nigeria. Journal of Sustainable Development, 6(12), 61. https://doi.org/10.5539/jsd.v6n12p61

Pfeffer, J., \& Pfeffer, J. (1981). Power in organizations Pitman Marshfield, MA.

Pfeffer, J., \& Salancik, G. R. (2003). The external control of organizations: A resource dependence perspective Stanford University Press.

Phillips, R. (2003). Stakeholder theory and organizational ethics Berrett-Koehler Publishers.

Phillips, R. A., \& Reichart, J. (2000). The environment as a stakeholder? A fairness-based approach. Journal of Business Ethics, 23(2), 185-197. https://doi.org/10.1023/A:1006041929249

Polonsky, M. J. (1999). The incorporation of an interactive external environment: An extended model of marketing relationships. Journal of Strategic Marketing, 7(1), 41-55. https://doi.org/10.1080/096525499346521

Prell, C., Hubacek, K., Reed, M., Quinn, C., Jin, N., Holden, J., . . Sendzimir, J. (2007). If you have a hammer 
everything looks like a nail: Traditional versus participatory model building. Interdisciplinary Science Reviews, 32(3), 263-282. https://doi.org/10.1179/030801807X211720

Preston, L. E., \& Sapienza, H. J. (1991). Stakeholder management and corporate performance. Journal of Behavioral Economics, 19(4), 361-375. https://doi.org/10.1016/0090-5720(90)90023-Z

Radcliffe, E. S. (1999). Hume on the generation of motives: Why beliefs alone never motivate. Hume Studies, 25(1), 101-122.

Reed, M. S., Graves, A., Dandy, N., Posthumus, H., Hubacek, K., Morris, J., . . Stringer, L. C. (2009). Who's in and why? A typology of stakeholder analysis methods for natural resource management. Journal of Environmental Management, 90(5), 1933-1949. https://doi.org/10.1016/j.jenvman.2009.01.001

Rhenman, E. (1964). Företaget som ett styrt system Ekonomiska forskningsinstitutet vid Handelshögsk. i Stockholm (EFI).

Roberts, R. W. (1992). Determinants of corporate social responsibility disclosure: An application of stakeholder theory. Accounting, Organizations and Society, 17(6), 595-612. https://doi.org/10.1016/0361-3682(92)90015-K

Robinson, A. (2005). Towards an intellectual reformation: The critique of common sense and the forgotten revolutionary project of gramscian theory. Critical Review of International Social and Political Philosophy, 8(4), 469-481. https://doi.org/10.1080/13698230500205045

Robinson, S. (2014). Introduction: Community journalism midst media revolution. Journalism Practice, 8(2), 113-120. https://doi.org/10.1080/17512786.2013.859822

Rowley, T. J. (1997). Moving beyond dyadic ties: A network theory of stakeholder influences. Academy of Management Review, 22(4), 887-910.

Salam, M. A., \& Noguchi, T. (2006). Evaluating capacity development for participatory forest management in bangladesh's sal forests based on '4Rs' stakeholder analysis. Forest Policy and Economics, 8(8), 785-796. https://doi.org/10.1016/j.forpol.2004.12.004

Savage, G. T., Nix, T. W., Whitehead, C. J., \& Blair, J. D. (1991). Strategies for assessing and managing organizational stakeholders. The Executive, 5(2), 61-75. https://doi.org/10.5465/AME.1991.4274682

Schiller, C., Winters, M., Hanson, H. M., \& Ashe, M. C. (2013). A framework for stakeholder identification in concept mapping and health research: A novel process and its application to older adult mobility and the built environment. BMC Public Health, 13(1), 1. https://doi.org/10.1186/1471-2458-13-428

Silk, J. (1999). The dynamics of community, place, and identity. Environment and Planning A, 31(1), 5-17. https://doi.org/10.1068/a310005

Sojinu, O. S., Wang, J., Sonibare, O., \& Zeng, E. Y. (2010). Polycyclic aromatic hydrocarbons in sediments and soils from oil exploration areas of the niger delta, nigeria. Journal of Hazardous Materials, 174(1), 641-647. https://doi.org/10.1016/j.jhazmat.2009.09.099

Solomon, L. (1960). The influence of some types of power relationships and game strategies upon the development of interpersonal trust. The Journal of Abnormal and Social Psychology, 61(2), 223. https://doi.org/10.1037/h0047571

Soukhanov, A. H. (1984). Websters II new riverside university dictionary Houghton-Mifflin Company.

Starik, M. (1995). Should trees have managerial standing? toward stakeholder status for non-human nature. Journal of Business Ethics, 14(3), 207-217. https://doi.org/10.1007/BF00881435

Stenseke, M. (2009). Local participation in cultural landscape maintenance: Lessons from sweden. Land use Policy, 26(2), 214-223. https://doi.org/10.1016/j.landusepol.2008.01.005

Sutterfield, J. S., Friday-Stroud, S. S., \& Shi vers-Blackwell, S. L. (2006). A case study of project and stakeholder management failures: Lessons learned. Project Management Quarterly, 37(5), 26.

Takon, N., Ali, S., Saeed, M., Hussain, J., Akinbileje, T. Y., Nwaozuzu, E. E., . . Sitters, C. (2014). Distribution of oil revenue to niger delta of nigeria in post-2000: Is the debate how fairly the federal government has redistributed oil revenue? International Journal of Development and Sustainability, 3(4), 586-607.

The new shorter oxford English dictionary. Oxford university press: uk, 1993, 455.

Thompson, J. K., Wartick, S. L., \& Smith, H. L. (1991). Integrating corporate social performance and 
stakeholder management: Implications for a research agenda in small business. Research in Corporate Social Performance and Policy, 12, 207-230.

Vandekerckhove, W., \& Dentchev, N. A. (2005). A network perspective on stakeholder management: Facilitating entrepreneurs in the discovery of opportunities. Journal of Business Ethics, 60(3), 221-232. https://doi.org/10.1007/s10551-005-0130-7

Walker, D. H., Bourne, L., \& Rowlinson, S. (2008). Stakeholders and the supply chain. Procurement Systems: A Cross-Industry Project Management Perspective, 70-100.

Walt, G. (1994). Health policy: An introduction to process and power.

Weber, M. (1947). The theory of economic and social organization. Trans.AM Henderson and Talcott Parsons.New York: Oxford University Press.

Welch, M., \& Jackson, P. R. (2007). Rethinking internal communication: A stakeholder approach. Corporate Communications: An International Journal, 12 (2), 177-198. https://doi.org/10.1108/13563280710744847

Wicks, A. C., Gilbert Jr, D. R., \& Freeman, R. E. (1994). A feminist reinterpretation of the stakeholder conce pt. Business Ethics Quarterly, 475-497. https://doi.org/10.2307/3857345

Wiesenfeld, E. (1996). The concept of "we": A community social psychology myth? Journal of Community Psychology, 24(4), 337-346. https://doi.org/10.1002/(SICI)1520-6629(199610)24:4<337::AID-JCOP4>3.0.CO;2-R

Wilson, W., \& Miller, N. (1961). Shifts in evaluations of participants following intergroup competition. The Journal of Abnormal and Social Psychology, 63(2), 428. https://doi.org/10.1037/h0043621

Wolfe, R. A., \& Putler, D. S. (2002). How tight are the ties that bind stakeholder groups? Organization Science, 13(1), 64-80. https://doi.org/10.1287/orsc.13.1.64.544

Wurthmann, G. (2006). Working Paper 84-Ways of using the African Oil Boom for Sustainable Development.

Yang, R. J. (2014). An investigation of stakeholder analysis in urban development projects: Empirical or rationalistic perspectives. International Journal of Project Management, 32(5), 838-849. https://doi.org/10.1016/j.jproman.2013.10.011

Yusuf, Y. Y., Gunasekaran, A., Musa, A., El-Berishy, N. M., Abubakar, T., \& Ambursa, H. M. (2013). The UK oil and gas supply chains: An empirical analysis of adoption of sustainable measures and performance outcomes. International Journal of Production Economics, 146(2), 501-514. https://doi.org/10.1016/j.ijpe.2012.09.021

Zander, A., \& Cohen, A. R. (1955). Attributed social power and group acceptance: A classroom experimental demonstration. The Journal of Abnormal and Social Psychology, 51(3), 490. https://doi.org/10.1037/h0040101

\section{Copyrights}

Copyright for this article is retained by the author(s), with first publication rights granted to the journal.

This is an open-access article distributed under the terms and conditions of the Creative Commons Attribution license (http://creativecommons.org/licenses/by/4.0/). 